\title{
The future of Sustainable Healthcare: Extending product lifecycles
}

\author{
Myriam Ertz ${ }^{1 *}$, Kubiat Patrick ${ }^{2}$
}

* Corresponding author

${ }^{1}$ LaboNFC, Université du Québec à Chicoutimi, 555 Boulevard de 1'Université, G7H 2B1 (QC) Chicoutimi, Canada. Tel : +1 418 545-5011, e-mail : Myriam_Ertz@uqac.ca

${ }^{2}$ LaboNFC, Université du Québec à Chicoutimi, 555 Boulevard de l’Université, G7H 2B1 (QC) Chicoutimi, Canada. Tel : +1 418 545-5011, e-mail : Kubiat_Patrick@uqac.ca 


\title{
The future of Sustainable Healthcare: Extending product lifecycles
}

\begin{abstract}
The business model theory has been applied across a variety of contexts and especially in order to develop more sustainable organizations. Given the rise in municipal solid waste emanating from healthcare institutions' disposition of durable or semidurable products, and the ensuing challenges arising both in the environmental and in the social realms, product lifetime extension constitutes a valuable approach to curb product disposition and contribute to sustainability. This paper explores product lifetime extension opportunities among healthcare institutions' third-party contractors who are in charge of supplying and maintaining products in the medical sector. Product lifetime extension business models involve either nature strategies that improve product durability through improved design or nurture strategies that prolong product lifetime while in use and as long as the product remains functional. The paper uses a case study approach to investigate organizations articulating product lifetimes extension in their business model blueprint. The business models are analyzed and compared to gain useful insights that will contribute to develop professional practice, future research as well as policy making and decision making that is focused on achieving through product lifetime extension.
\end{abstract}

Keywords: sustainable healthcare; product lifetime; product lifetime extension; business model; third-party contractors; medical waste.

\section{Research background: the need for product lifetime extension in the healthcare sector}

The healthcare industry faces many challenges, but one particular characteristic of this sector compared to others is its slow adaptation to the sustainability movement (Tran, 2016). The main reason for this lack of focus on sustainability has been the prioritization of patient safety first above all other considerations (Abouelmehdia et al., 2017). Yet, according to the World Health Organization (WHO), modern healthcare facilities generate large amounts of solid waste such as disposable medical devices and 
electronics, plastics, bandages, furniture, and many more ${ }^{1}$. In addition, between $15 \%$ and $25 \%$ of the total healthcare waste contains radiological, biological or chemical hazards ${ }^{2}$. These vast quantities of waste are all the more expected to rise with world population ageing (United Nations, 2017). In fact, the number individuals aged 60 years or over in the world is expected to double by 2050 to reach some 2.1 billion (United Nations, 2017).

Meanwhile, the uptake in solid municipal waste from the healthcare sector is not only damaging for the environment but also hurtful economically, since discarded parts, products, and material in general mean discarded (financial) resources (Martin and Schouten, 2012; The Ellen MacArthur Foundation, 2015). It has been reported that, in the healthcare sector, there is a dearth of competent management of the existing services; not limited to just time and human resources solely but also to materials and equipment used to perform these duties (Smith et al., 2013). Inventory supply management used to be one of the greatest challenges facing the healthcare sector (Saghbini, 2016). It is estimated that the cost of purchasing new equipment annually has increased by more than 5 percent over the last 20 years making profit margins unbearable and thus resulting in the increase of medical services and insurance fees within every five year (Saghbini, 2016). Overall, the current use of single-use diposables (e.g., disposable custom packs) in healthcare has become costly, wasteful, and often unnecessary (Campion et al., 2015).

Therefore, it is both responsible and strategic for health care sector organizations, citizens and society in general to try to curb product disposition rates in the sector.

To limit product disposition, medical organizations need to embrace eco-efficiency which is the saving of not only energy, but also materials (Bocken and Short, 2016). From an eco-efficiency perspective, product lifespan is directly affected by environmental concept choices, making supply chain management but also post-production cycles such as consumption, usage, and redistribution. All these

\footnotetext{
1 WHO (2012). Heakth care solid waste. Available at: https://www.who.int/sustainable-development/healthsector/health-risks/solid-waste/en/ (retrieved on 30/05/2019).

${ }^{2}$ Ibidem.
} 
different stages and actions pertaining to the product could actually be acted upon to reduce rapid product disposition.

Beyond the health care sector, a growing number of scholars contend that the current linear “extraction-production-consumption-disposal" schematas of product lifecycle, should be replaced by circular product lifetimes through which the lifetime of a given product is continuously extended as long as possible or recycled when reaching its end of life (Van Nes and Cramer, 2006; Wilhelm, 2012; Maldini et al., 2019). Such initiatives are often called product lifetime extension strategies (Box, 1983) and fit in the broader concept of circular economy (The Ellen MacArthur Foundation, 2015). Product lifetime (PL) is defined as "the duration of the period that starts at the moment a product is released for use after manufacture and ends at the moment a product becomes obsolete beyond recovery at product level" (Den Hollander et al., 2017, p. 519). Thus product lifetime extension (PLE) refers to the means used to extend that duration (Van Nes and Cramer, 2003, 2005, 2006). Besides, PLE typically excludes end-of-life treatment such as reutilization in the form of recycling for example (Den Hollander et al., 2017). PLE is enacted through a variety of entities that can be generically denominated as product lifetime extension business models (PLEBM) and which aim at improving product design (nature strategies) (Bakker et al., 2014a; Van Nes and Cramer, 2003) or increase the lifetime of the product during post-production phases (nurture strategies) (Cox et al., 2013; Bakker et al., 2014b). Any organization could constitute a PLEBM for as long as it contributes to increase product lifespan. However, despite the many desirable aspects pertaining to PLE in terms of both ecological and economic benefits, and its widespread application to various products such as cars (Kagawa et al., 2006), consumer electronics (Wilhelm, 2012), or air conditioners (Nishijima, 2016), there remains a dearth of studies on PLE initiatives and opportunities in the healthcare sector.

Sustainability-related research in the healthcare sector, has mainly focused on recycling and its benefits for gas emission reduction, material or resource depletion prevention, pollution reduction, and safe energy promotion, by reducing the consumption of new raw materials (Kaiser et al., 2001; Karlsson 
and Öhman, 2005). Besides, research has also shown that many healthcare centers have started to get involved with the Go Green initiative, while some have already taken action by using reusable medical products (Eckelman et al., 2012). For example, a recent experiment conducted by scientists of disposable and reusable laryngeal mask airways found that the reusable mask was a more effective and affordable option compared to the disposable ones which increases the waste management workload (Eckelman et al., 2012). Likewise, Campion et al. (2015) showed that cotton products in the healthcare industry should be considered for reuse, and not discarded after one single use.

PLE approaches are more fitting for durable or semidurable products (Cooper, 2004, 2010). Besides, although recycling incurs desirable properties, the focus on PLE is based on the finding that "reusing, when possible, is preferable to recycling because the item does not need to be reprocessed before" (Bhamra and Hon, 2004, p. 223). Extant research has made a strong case in determining the extent to which reuse applies to numerous product categories (Yokoo and Kinnaman, 2013; Falk and McKeever, 2004). Therefore, in this study, the notion of product refers to : (1) durables, i.e., solid medical device that does not immediately wear out, but produces results over time (e.g., CT scan, EMR); and (2) semi-durables, i.e., medical supplies that last for a given amount of time (e.g., medical clothing, surgical apparatus and furniture).

This paper takes third-party contractors, doing business with healthcare institution, as the unit of analysis since these organizations are in charge of a great variety of PLE-related tasks including product design and production or waste management (Kane et al., 2018). Focusing on these organizations will also provide a better insights onto the extent to which the health care sector might take a prominent role in moving towards sustainability, and what business models might contribute to this endeavor by extending product lifecycle. Drawing on our definition of PLE focusing on design, consumption and postconsumption phases, this study presents a range of innovative cases in the health care sector. These cases show that marrying profitability and sustainability in the healthcare sector is possible, through a combination of key PLE activities such as design, access, maintenance, redistribution, and recovery. 
These PLE business models that are specific to the healthcare sector can be durable while contributing to curb product waste, and hence, resource and financial waste. This study answers the following research question: How can product lifetime extension contribute to sustainability in the healthcare sector?

In this study, we examine the opportunities of product lifetime extension business models for the healthcare sector using a case study methodology to assess the extent to which such initiatives are realistically designed and managed. We apply the product lifetime extension business model (PLEBM) (Ertz et al., forthcoming) framework to analyze the key features of sustainable solutions in the healthcare sector. Section 2 consists of a review of the literature on product lifecycle extension and its frontiers namely in relation to nomologically- and semantically-close concepts. Section 3 introduces the research methodology. Section 4, describes and analyzes three business models using the product lifetime extension business model (PLEBM) framework. Finally, section 5 provides a discussion of the cases and implications for theory and research, while the conclusion in section 6 elaborates on study limitations and future research avenues.

\section{Literature review}

\subsection{Perspectives on product lifetime and product lifetime extension}

Although very specific, the concepts of product lifetime and product lifetime extension are also conceptually germane to a set of other related concepts (Cooper, 1994) and as such can be very confusing. This section will draw the frontiers and boundaries of PL and PLE with other associated constructs to avoid ambiguities while exposing potential theoretical interlinkages.

First, PL differs from product life-cycle (PLC) which is used in different areas. In marketing and consumption studies, it refers to the passage through a series of stages, namely development, marketing introduction, growth, maturity and decline (Levitt, 1965). Closely related to PLC, product life-cycle management (PLM) thus refers to the different marketing strategies in terms of product features, pricing, distribution, and communication that need to be used in each phase (Anderson and Zeithaml, 1984). 
Whenever healthcare products are introduced into the marketplace, not all of them undergo the five stages at the same time or at the same duration, and some products can actually skip a few stages but they all are presumed to reach the same conclusive state of decline. Although from a PL viewpoint, PLE could apply across the five stages of the PLC, the marketing literature typically situates product lifespan extension opportunities at the final stage of decline. Conversely, during the product introduction stage the product sales continually increase to encounter a plateau. Gradual growth is obtained over a moderate period of time but like most healthcare product it never remains at the peak level for long before hitting the maturity stage (Okoye, 2015). During the maturity stage, an increase in sales encourages intense competitors, if demand does not meet supply in most situations that is when the sales of product start to decline.

Second, in management and information systems, product lifecycle management (also, PLM) closely related to product data management (PDM) refers to "a systematic, controlled concept for managing and developing products and product related information. PLM offers management and control of the product (product development, productizing and product marketing) process and the order-delivery process*, the control of product related information throughout the product life cycle, from the initial idea to the scrap yard" (Saaksvuori and Immonen, 2008). This conceptualization of PLM is closer to PL in that the core objective is to use database management systems and information management processes across the product lifecycle to better control, manage and extend product longevity (Bhamra and Hon, 2004). The ELIMA (Environmental Life Cycle Information Management and Acquisition) for consumer products system ${ }^{3}$, funded by the European Commission constitutes an example of such a PLM. ELIMA provides a database and management software to collect and analyze information throughout the life cycle (i.e., component supplier, producer, distributer/retailer, user, maintain/refurbish, end-of-life treatment, recycling/reuse) (Simon et al., 2004). Some researchers have reported logistic and operational issues as a

\footnotetext{
${ }^{3}$ CARE Electronics. ELIMA - Environmental Life Cycle Information Management and Acquisition for Consumer products. Available at : http://www.4980.timewarp.at/CARE/elima.html (accessed on 31/05/2019).
} 
major hindrance in refurbishing healthcare products. In fact, Cormican and O'Connor (2009) illustrated that if the sequence of stage is not properly observed during technological transfer (i.e., product takeback), a state of improvement or extension in the technology (equipment) itself, can never be reached. DMD Connects (2015) suggests that extending the pharma product life cycle with competent strategies can only occur if brand managers including marketing executives pay closer attention to factors that influence the market like prescription behaviors and direct involvement with consumer education.

Third, in the environmental sciences, in industrial ecology and in engineering, it is very common to speak of life cycle assessment (LCA) which refers to a technique that is used to assess the overall environmental impacts associated of a product through all stages of a products life (Finnveden et al., 2009). These stages generally include raw material extraction, materials processing, manufacture, distribution, use, repair/maintenance, disposal and recycling (Cooper and Fava, 2006). Most healthcare firms quickly conduct cost effective alternative models life-cycle assessments, or comprehensive extension business plan that can increase product lifespan, irrespective of the final solution to product lifecycle extension. Besides, most sustainable extension plan in the healthcare industries did not begin with a primary plan on sustainable healthcare but this is not to say that the extension of a project life cycle cannot be introduced at any stage of the entire product life cycle. Overall, although not yet a deeply rooted practice in healthcare, some authors (e.g., Campion et al., 2015) suggested the use of the LCA approach by healthcare institutions to make environmental improvements.

Fourth, a distinction needs to be made between the technical, service, economic, aesthetic and life of a product (Cooper, 2010). First "a product's 'technical life' is the maximum period during which it has the physical capacity to function" (Cooper, 2010, p. 9). This is rarely reached and instead we speak of a product service life which is "a product's total period in use from initial acquisition to final disposal as waste" (Cooper, 2010, p. 9). As such, technical life is close to the notion of product durability, which is "the ability of a product to perform its required function over a lengthy period under normal conditions of use without excessive expenditure on maintenance or repair" (Cooper, 1994, p. 5). In principle, durability 
life will be lower than technical life since a given product will inevitably require repair after some time. Importantly, these types of engineering-based perspectives on product lives are theoretically determined by design and manufacturing (hence, production) factors.

Therefore, to acknowledge the wider forces that shape a product life, research has devoted more attention to the consumption or usage phase. from a single consumer viewpoint, product lifetime conflates with replacement life, which is "the period from initial sale to the point at which the owner purchases a replacement, regardless of whether or not the original product still functions" (Cooper, 2010, p. 9). Replacement life could further conflate with aesthetic like of economic life. In fact, a consumer might replace a product the ageing of that product is perceived negatively (i.e., aesthetic life) (Cooper, 2010) or if the maintenance of the product becomes more costly than replacing it (i.e., economic life) (Heiskanen, 1996; Kostecki, 1998). In some cases, the ageing of the product in the "patina of wear" or other forms of product aesthetic degradation can be positively assessed and in that case, the product aesthetic life is prolonged (McCoy, 1997; Van Hinte, 1997). While replacement life better emphasizes the subjective factors of user behavior, attitudes and wider socio-cultural influences on product lifespan, this consumerbased perspective remains too narrow, since the micro-centered perspective of the consumer misses the wider expanse of the potential technical life nexus, which is theoretically much longer.

Yet, instead of an engineering-based view of product lifespan, that is rarely reached and that does not acknowledge external interventions (e.g., user behavior, wider socio-cultural influences), and instead of a socio-cultural perspective that remains too subjective and too narrow to align with the broader technical life of the product, some studies have advanced the notion of product "longetivity" or "lifetime". Product lifetime encapsulates the improvement of intrinsic product durability, also known as a nature strategy, to extend the technical life or durability of a product (Bakker et al., 2014a; Van Nes and Cramer, 2003). Besides, PL also encompasses the deliberate efforts "to utilize fully a product's potential life-span, through careful use, regular maintenance, repair, reconditioning (e.g. upgrading) and reuse of functional items (rather than disposal)" (Cooper, 2010, p. 8), which can be considered as nurture 
strategies (Cox et al., 2013; Bakker et al., 2014b). Product lifetime (PL) is thus defined as "the duration of the period that starts at the moment a product is released for use after manufacture and ends at the moment a product becomes obsolete beyond recovery at product level” (Den Hollander et al., 2017, p. 519). Product lifetime extension (PLE) refers to the means used to extend that duration (Van Nes and Cramer, 2003, 2005, 2006). As such, PLE typically excludes end-of-life treatment such as reutilization in the form of recycling for example (Den Hollander et al., 2017). From an operational viewpoint, product lifetime extension needs to occur in a specific framework, typically a business-centered one, called a business model perspective, in which different activities, systems, processes, and resources are coordinated to produce value. The next section elaborates on this concept and proposes a framework for business model extending product lifetimes.

\subsection{A framework to analyze product lifetime business models extension}

We introduce a business model perspective to the study of PLE initiatives in the health care sector. The business model perspective has been widely acknowledged across the sustainability literature as a useful framework to map, analyze and compare, on an equal footing, heterogeneous businesses, as underscored by various reviews of sustainable business models in the literature (e.g., Lewandowski, 2016; Nosratabadi et al., 2019; Tunn et al., 2019). In this study, we draw on a specific business model framework that has recently developed to analyze business models, that extend product lifetimes: the product lifetime extension business model (PLEBM) framework (Ertz et al., forthcoming). The PLEBM

lens is used to analyze real-world cases and to develop recommendations for future PLE in the healthcare sector.

\subsubsection{The product lifetime extension business model framework for the healthcare sector}

According to past research, "business models define the way a firm does business" (Bocken and Short, 2016, p. 44), and include the following elements: value proposition (product service offering), value creation and delivery (e.g., key activities, key resources, key partners, customer segments) and 
value capture (cost and revenue stream)" (Osterwalder and Pigneur, 2010), as shown in Figure 1. The PLEBM framework is an adaptation of the generic business model theory, applied to the analysis of business models that extend PL (Ertz et al., forthcoming). As such, it encompasses value proposition, value creation and delivery (excluding resources, which are pre-owned or products in all cases), as well as value capture (excluding cost structures, which are typically hard to obtain, especially in an accurate form and from an outsider perspective).

[INSERT FIGURE 1 ABOUT HERE PLEASE]

\subsubsection{The dimensions of the product lifetime extension business model framework}

The PLEBM comprises eight key dimensions and corresponding variables: product service offering, key activities, key resources, key partners, customer segments, distribution channels, customer relationship and revenue streams.

Product service offering. Also called offering or offer, this dimension refers to the value proposition of the business, that is, the value created for customers through the bundle of products and services offered by the organization (Ertz et al., forthcoming). A company's offering of PLE can be either core or secondary (Nussholz, 2017):

(1) A core PLE offering: the company explicitly positions itself as enabling PLE;

(2) A secondary PLE offering: an incidental outcome of organizational activities resulting in PLE.

Key activities. These refer to activities that involve PLE processes, systems and procedures. There are four overarching PLE activities based on literature that extend PL:

(1) Improved product design: improvement of product and production processes as well as improved design for repair (Cox et al., 2013; Bakker et al., 2014b); 
(2) Access: use-oriented service scape including leasing, renting, mutualizing and pooling to temporarily transfer a product from an individual who does not want or need to another individual who wants or needs it (Mont, 2002; Tukker, 2004);

(3) Maintenance: product-oriented service scape including maintenance, advice, training and consultancy contracts (Gaiardelli et al., 2014);

(4) Redistribution: product transfer activities from one individual to another through various activities such as donation, swapping and second-hand purchase (Harrell and McConocha, 1992; Hanson, 1980);

(5) Recovery: restoring a given product to an initial state of functioning through product repair or remanufacturing, refurbishing, repackaging, or reconditioning (Bakker et al., 2014a; Den Hollander et al., 2017).

PLE excludes end-of-life treatment in the form of reutilization of materials through recycling for example (Den Hollander et al., 2017).

Key resources. Key resources typically involve : (1) pre-owned (or used) products or parts, components, and materials; (2) new products that are typically lended, leased, shared or pooled; and (3) new parts, components and raw materials that, similarly to pre-owned ones, will be used either in the design of longer-lasting product or in the recovery or maintenance of existing products. Ideally, all input parts, components, or materials should be pre-owned or recycled to further embed the business model in a circular economy model.

Key partners. Describe "the network of suppliers and partners that make the business model work" (Osterwalder and Pigneur, 2010, p. 38). Ertz et al. (forthcoming) consider both organizations and peers as meaningful partners to extend product lifetimes. Key partners mostly include third party contractors like maintenance groups performing specific or routine hospital functions or works directly with supply chain management. For example, the environmental health and safety departments working 
with health sustainability companies including medical waste management groups. Also, regional hospital may rely on third-party vendors for supplies and regular maintenance.

Customer segments. Customer segments are typically organizations (i.e., B2B or $\mathrm{O} 2 \mathrm{O}$ ) or consumers (i.e., B2C or O2C). Yet, Ertz et al. (forthcoming) also added a third possibility as consumer exchanging to other consumers (i.e., $\mathrm{C} 2 \mathrm{C}$ ) and further integrated consumers trading with organizations (i.e., $\mathrm{C} 2 \mathrm{~B}$ or $\mathrm{C} 2 \mathrm{O}$ ). In the healthcare sector, manufacturers of hospital and medical apparatus such as wheelchairs, diagnostic equipment, canes, walkers, rollators, or power scooters that are commercialized to not only hospitals and clinics but also to end consumers through via the Internet or in drugstores, are operating in both B2B and B2C segments while possibly allowing for $\mathrm{C} 2 \mathrm{~B}$ and even $\mathrm{C} 2 \mathrm{C}$ as well.

Distribution channels. Channels include all the distribution circuits that enable to extend PL as shown in Figure 2. Supplementing these principal channels in healthcare PLE shows the importance of information flows between stakeholders, the flow of information also plays a vital role in the project success. In the healthcare sector, all channels are of relevance with the exception perhaps of peers touchpoints unless peers exchange pre-owned medical items with each other. Otherwise, the mail/transportation channel is of particular relevance since many PLE initiatives are built in conjunction between healthcare institutions and third-party contractors such as suppliers or waste management professionals. For example, a third party may deliver the drum and cardboard paper for hospital's medical deposit and then collect the waste for potential reuse.

\section{[INSERT FIGURE 2 ABOUT HERE PLEASE]}

Customer relationship. This dimension refers to the types of relationships that a company typically establishes with specific customer segments (Ertz et al., forthcoming; Osterwalder and Pigneur, 2010). Past literature differentiated between transactional relationships, through which only a good or a service is exchanged, and relational relationships which involve more frequent and personalized interactions over the long-term (e.g., preventive or full maintenance services, training sessions). The idea 
of either using transactional or relational building block as the sole process of healthcare delivery product has since been intertwine with the mixing of both forms of customer relationships. The process of merging both services together has established more unique inter-organizational trust and faster effective services within the healthcare industry. Through service level agreements (SLAs), companies do not only deliver goods and services, but provide training, advice, consultancy and maintenance services for clients which in turn has created more job, save time, resources and manage medical waste to some extent. For example, a manufacturing company like Siemens provides the equipment, but send also instructors and technicians to train healthcare staffs and provide other avenues for non-staff to learn the skill process of maintaining and carry out operations too.

Revenue stream. Revenue streams refer to the cash that an organization generates from market segments (Ertz et al., forthcoming; Osterwalder and Pigneur, 2010). As shown in Figure 3, revenues can accrue from a variety of PLE-related activities ranging from reselling of a pre-owned product to lending fees or advertising revenues. This dimension is closely related to the key activities one. If a children's hospital is planning to open a new surgical operating room, funds can be gathered through any of the above revenue streams and still serve the same function in the end.

\section{[INSERT FIGURE 3 ABOUT HERE PLEASE]}

\section{Method}

In order to develop the conceptualization of product lifetime extension business models within the health care sector, this study employs an exploratory research focus because as of now, little research has been done on this topic (see Kane et al., 2018, for an exception), and exploratory approaches are more suitable in under-theorized areas of research (Patton, 2002). More specifically, the study takes a casebased approach in order to develop a holistic and realistic perspective in order to develop insights into the how and the why questions in a contemporary topic (Yin, 2014), such as sustainable healthcare. 
The selection of the cases was based on the review of the database of 150 business models studied by Ertz et al. (forthcoming) to develop their PLEBM, as well as on the personal experience of one of the authors who practiced as a medical doctor (MD) in the United States. Since Ertz et al's (fortcoming) sample already screened organizations involved in PLE, the selection criteria for the other companies included in the analysis, was based on their active involvement in sustainability, in general, and product lifetime extension policies, in particular (see Table 1, column 3). As shown in Table 1, a total of five companies were selected as case studies.

In all cases, a thorough web content analysis was performed in order to glean as much information as possible along the PLEBM dimensions and variables, for each firm. When possible, interviews with key human resources were performed within the organization to complement content analysis. The case studies explored the following building blocks:

(1) value proposition: the product service offering of the business model;

(2) value creation process: the key activities of the firm, key resources used and its key partners;

(3) the value delivery process: customer segments, distribution channels and customer relationship;

(4) value capture: the revenue streams of the firm.

\section{[INSERT TABLE 1 ABOUT HERE PLEASE]}

\section{Case studies}

In this section, we describe the three case studies, and their relation to product lifetime extension.

\subsection{Stericycle - Regulation-compliant medical waste management}

Stericycle is a global leader in the provision of suites of highly specialized solutions to serve healthcare organizations as well as commercial businesses. The company was founded in 1989 as a small start-up in medical waste management that aimed at assisting healthcare providers comply with new 
medical waste regulations. Currently, Stericycle has grown into a full-fledged provider of sustainability services operating in 23 different countries and employing more than 24,000 employees.

Stericycle's business model is based on a commitment to protecting the environment and support social responsibility across all the communities in which it is involved. As such, it operates on premium pricing and offers a wide range of programs that ensure safe and easy disposal of medical products (e.g., medications, sharps, batteries) in compliance with both provincial and federal regulations. Apart from medical waste management, the organization provides also communication services, environmental consulting services, and training programs. Stericycle's core principle is to save companies money and also educate them on the principle of an environmentally superior (i.e. less waste, energy, chemicals, pure natural air) alternative to recycling waste material.

During the cases of quarantine in the 2014 Ebola crisis in the USA, and natural disasters (e.g., Hurricane Harvey flood and California's wildfires), Stericycle partnered with local, state and federal governments to manage and transfer medical waste to temporal and permanent disposal sites. These processes allowed Stericycle workers to contact lay residents who are not their regular partners. Stericycle uses different types of communication systems with their clients like the 24/7 answering services, messaging solutions and patients access services. Although Stericycle is also an educational platform informing on regulation compliance, it went public on NASDAQ AS SRCL in 1996. The aim of Stericycle was to reach every country, and accordingly it has expanded to the 5 continents while its revenues have gone beyond 1 billion USD since 2008 and have amounted to more than 3 Billon USD in 2018.

\subsubsection{PLE-related elements in Stericycle business model}

The main responsibility and competency dimension of Stericycle business model is based on featured services turning hazardous waste material from any industry to reusable sustainable material. More specifically, the organization provides product recall services by delivering recall consulting and 
execution for a great variety of industries including medical devices, pharmaceutical, health and beauty, appliances, retail and more. Further, Stericycle also manages product returns through reverse logistics solutions (e.g., ExpertSOLUTIONS®), involving manufacturers, distributors, retailers and the supply chain in its entirety. The organization also offer consumer and retailer product retrieval through direct representatives (i.e., ExpertFIELD FORCE®). Product retrieval may arise due to customer complaints, product withdrawals or product recalls and Stericycle ensures compliance with the retrieval requirements.

Finally, in addition to providing product recovery through reversed supply chain management, Stericycle also offers a variety of maintenance services by providing various compliant disposal and regulatory training, consultancy and advice services in the healthcare industry.

\subsection{Layer- Industrial and digital designers}

Layer is a start-up composed of a close-knit team of industrial and digital designers, artists, engineers, researchers, experience experts, and branding specialists from around the world. The Layer studio in the heart of east London and provides a platform for collaborative design, powered by a close working relationship with customers.

The Layer team's business model is centered around the creation of premium priced and exclusive products that are aimed at "reshaping" the way people live, work, travel and communicate in the future. To do so the organization implements strategic ideation to implementation. Examples of products that have resulted from this process, include smart wearables and furniture systems, communication tools and devices incurring artificial intelligence. Although not specialized in the medical sector per se, the organization's focus on wearable devices, industrial and digital design, as well as sustainability have made it a rising reference in the healthcare sector among both organizations and consumers alike.

Recent flagship products espousing the tech-powered sustainability positioning of Layer include the GO wheelchair, a made-to-measure 3D-printed consumer wheelchair that is customized to individual needs thanks to 3D digital data and biometric information mapping. The companion GO app involves 
consumers in design and provides advices and options to improve the maintenance of the product. The studio further produces a wide range of products using minimalist yet improved design to develop longerlasting, and often connected products such as smartwatches straps (i.e., future fixation), tactile touchpoints, flexible furniture, or moving materials. The company even claims that some product prototypes such as Ripple® are " $400 \%$ sustainable" since they use a new process for corrugating plywood to produce ultra lightweight products with minimal environmental impacts.

\subsubsection{PLE-related elements in Layer's business model}

In their classification of PLEBM, Ertz et al. (forthcoming) determined that there are comparatively much less organizations focusing on improved design than on the other four key activities of PLE. Layer belongs to those exceptions by focusing on both industrial design and digital design. On the one hand, industrial design aims at crafting products that are easier to use while also longer-lasting to reach sustainability. Through digital design, the team develops an app for all the products designed via industrial design. The application provides useful tracking metrics but also advice, and training for product users, ensuring better product maintenance. For example, the Pal® modular personal transport system is a good manifestation of how both design types combine. On the one hand, PAL is has a minimalist design and consumes the supposedly cleaner electric energy. On the other hand, PAL embraces artificial intelligence and machine learning, to inform users about a variety of themes including travel routes, lengths, traffic, or user habits, but also product state and maintenance needs.

\subsection{AGITO Medical - Pre-owned medical equipment provider}

AGITO Medical provides an alternative to the high cost of many original equipment manufacturer (OEM) equipment that are highly capital-intensive, such as mainly magnetic resonance imaging (MRI), computed tomography (CT), as well as ultrasound systems and probes, but also other equipment (e.g., Carm, mammography). The organization operates with offices in France, The Netherlands and Denmark. 
The business models focuses on the commercialization of pre-owned medical equipment, on the rental of such equipment and on the commercialization of spare parts. Due to the crucial necessity for safety and quality in the medical devices industry, the company's rental solutions are ISO 13485 certified and the organization claims to follow the high standard of ethical principles as delineated by the International Association of Medical Equipment Remarketers and Services), an organization in which AGITO Medical is also represented at the board of directors.

Since April 2018, AGITO Medical has been acquired by Philips Healthcare to operate under the Multi-Vendor Services (MVS) team. The MVS teams is notably a key enabler within Philips for what the company terms "Managed Maintenance Services and Long Strategic Partnership" value proposition in order to develop more relational links with customers. As such, AGITO Medical's business model aims mainly at relational links with customers. Moreover, the company's recent affiliation with Philips Healthcare, spurred a scaling up of company operations that manifested in new partnerships and contracts (e.g., German Private Hospital Group Ernst van Bergmann in Potsdam, Germany) and expansions to the rental solutions fleet. The acquisition has been mutually beneficial because since this acquisition, Philips Healthcare positively differentiated itself from its main competitors, Siemens Healthineers and GE Healthcare, PLE-wise. While the latter two firms remained specialized in conventional recoveryredistribution of medical systems (i.e., medical systems refurbishing), and maintenance, with productrelated services, Philips Healthcare, expanded beyond these activities, by offering highly flexible and customized access services, improved maintenance services such as equipment lifecycle management, and upgrades, but also education, training and consulting programs, as well as more effective reverse logistics through improved trade-in schemes. In sum, AGITO Medical contributed to Philips Healthcare's improved redistribution and maintenance practices, as well as introduction of access schemes.

\subsubsection{PLE-related elements in Agito Medical's business model}


The business model of the company is completely aligned with PLE in several aspects. First, the company engages in redistribution through reselling by commercializes pre-owned medical equipment that is usually supplied by the company's clients or non-clients through trade-in schemes or by partner OEM such as Philips, GE or Siemens. Typical suppliers thus include, but are not limited to, hospitals, clinics, laboratories, distributors, or bioengineering departments. Second, instead of owning equipment, organizations have the option to access desired equipment such as customized medical trailers or modular buildings through short- or long-term rental contracts. Third, product maintenance services are offered via warranties, but also a variety of advice contracts and maintenance contracts as well as full logistics services related to the management of rented products such as equipment dismantling, packaging, loading, and transportation. Finally, although not constituting a direct PLE activity, the recovery and re-commerce of spare parts as a form of reutilization could contribute to PLE indirectly by providing the required materials to perform product recovery through reparation, remanufacturing, refurbishing, repackaging, or reconditioning.

\subsection{Summary of the case studies}

Using the PLEBM framework (Ertz et al., forthcoming), Tables 2 and 3 provide respectively a summary and a detailed analysis of each of the three case studies. In all three examples, sustainability lies at the core of the business model definition although PLE is central to two out of the three firms.

The value proposition of companies show that although sustainability lies at the core of the three companies' business model definition, PLE is only central to two out of the three firms.

Second, the value creation and delivery involves pre-owned products in all cases except that of Layer which is focused on new products. While both Stericycle and Agito Medical's PLE activities range across all the nurture strategies, Layer is clearly positioned on a nature strategy with product design and some maintenance along with the product. A strong emphasis is thus put on product management and handling process for Stericycle and AGITO Medical, while at Layer, product lifetime extension is all 
about applying a "robust design process" ranging from strategic ideation to implementation: 1) partner (with other startups) using collaborative brief creation, brand immersion, and consumer workshops; 2) discover consumer behaviors and mindsets, using ethnographic research, market benchmarking and competitor analysis, trend research and technology roadmap; 3) define a series of concepts using functional architecture, design language, concept generation; 4) refine design form using photorealistic visualization, functional mock-ups, appearance models and mechanical engineering; and 5) deliver the end product using design for manufacture, supplier sourcing, art direction and communication strategy. Both Stericycle and AGITO Medical partner with a wide range of organizational partners who supply them with pre-owned medical products that they re-commerce through redistribution or access after potential recovery. However, since it offers rental solutions, AGITO Medical also uses fleets of new products that get extended through continuous short- or long-term rental contracts. In contrast, Layer develops its own new products and thus partners essentially with influential brands and "forward-thinking startups" especially during the partner phase of the design process (i.e., ideation process). Yet, partnerships may unfold throughout other subsequent stages as well. The three companies share similar channel characteristics since all of them use store, mail/transportation, and direct employees. The capitalintensive nature of the products and complex service levels of the services offered prevent these organizations from deploying a digital transactional platform on which clients can conduct commercial transactions. Instead, each firm provides a digital interactive platform as a vitrine. Yet, PLE initiatives are not always easily identifiable especially when the company is not specialized in PLE such as Stericycle and Layer. This ergonomic configuration of websites dilutes PLE efforts making them less salient and consequently less actionable for clients. With regards to customer segments only Layer differs from a purely inter-organizational perspective by addressing the B2C market. Business relationships are neither purely transactional neither purely relational, but rather a mixture of both across all three cases. This may be due to the diversity of product types in the heathcare sector ranging from benign such as masks or syringes, that are automatically repurchased in a transactional manner through electronic data interchange 
(EDI) systems, to high-end scanners or laser equipment requiring much more close and long-lasting relationships.

Finally, since both AGITO and Stericycle engage in a wider spectrum of key activities including not only redistribution but also maintenance through education and training programs as well as access solutions, for AGITO, the revenue streams are more diversified comprising not only asset sales but also usage fees, and for AGITO, lending and subscription fees in compensation of rental solutions. Layer in contrast relies exclusively on asset sale which includes extended warranty price.

[INSERT TABLE 2 ABOUT HERE PLEASE]

[INSERT TABLE 3 ABOUT HERE PLEASE]

\section{Discussion}

This papers draws upon the product lifetime extension business model framework (PLEBM) applied to the healthcare sector in order to show how PLE can be embodied in multiple ways across thirdparty healthcare service providers.

\subsection{Discussion and comparison of PLEBM}

The case studies provide meaningful approaches to integrate viably PLE in business models in the healthcare sector to curb current product disposition rates. First, it is important to mention that there appear to be two major orientation towards PLE. One is focused on nurture strategies (Cox et al., 2013) consisting in increasing PL through access schemes, for which it is in the owner's interest to extend PL to its fullest, but also redistribution, maintenance and recovery. The other is focused on nature strategies (Cooper, 2010) through improved product design. None of the case studies adopts both orientations simultaneously. This is not so surprising since either comes with a series of strategic implications. While both approaches to PLE do not differ in terms of channel types and customer relationship, they do in 
terms of offering, key resources, activities, revenues, and to some extent, customer segments and key partners.

More specifically, nature strategies (i.e., Layer) focus mainly on improved product design using various design techniques. Yet, improved design means manufacturing new products. As such, this strategy requires access to components, parts, and raw materials, more preferably reused or recycled ones that may further be reused and recycled, but this is not always feasible. 3D Printing technologies provides fruitful areas of PLE in this regard (Despeisse et al., 2017), with the possibility to print parts using renewed and renewable material. Producers could also use recyclebots to recycle materials that will further be used in the composition of their products (Zhong and Pearce, 2018). In contrast, nurture strategies rely on integer pre-owned products that may, at worst, necessitate some spare parts for recovery purposes. Further, with nature strategies, key activities are limited to improved design and possibly maintenance activities, which also reduce the sources of revenues to mainly asset sale. In contrast, nurture strategies span the broader spectrum of PLE activities, complementing maintenance with access, redistribution and recovery. As a consequence, revenue streams comprise not only asset sale but also usage fee, lending fee, and subscription fee. While, customer segments could be either B2B or B2C across both strategies, it appeared that Layer, the nature strategy firm, focused on both organizations and consumers as clients, whereas both AGITO Medical and Stericycle concentrate on organizations. Finally, key partners are essentially organizations and possibly peers in nurture strategies but are more limited to organizations during the ideation process or other phases of the design process, in case of nature strategies, unless the organization provides a consumer co-creation platform (Prahalad and Ramaswamy, 2004), such as open source design or co-production with consumers.

\subsection{Drivers of product lifetime extension in the healthcare sector}

The case studies showed that there are several enablers for the successful implementation of PLE in the healthcare sector: 
1. Strong sustainability-driven mission, vision, values and corporate motivation. This applied across all three firms. (Stericycle, Layer)

2. A strong focus on user convenience with the idea that lifetime-extended products must also come with specific benefits such as higher flexibility, lower prices, and so on. (all)

3. A strong focus on client needs and wants which is manifest in the focus on relational links with clients. (all)

4. A strong focus on quality and durability. (Layer, AGITO Medical)

5. The development of a strong network of partners and suppliers to access to the best pre-owned products, parts, components or raw materials. (all)

6. A diversified distribution circuit - shift toward integrated channels (i.e., omnichannel). (Layer)

In the previous section, it has been mentioned that there are roughly two major orientations to PLE to spur sustainable healthcare. Past research emphasized that nature strategies are less popular than nurture ones due to the fear of lack of profitability (Ertz et al., forthcoming). Similarly, the fear of facing competitive disadvantage because of lower sales and profitability explains firms' lower likelihood to engage in sufficiency-based business models (Bocken and Short, 2016). According to past research, only only luxury brands seem to be able to devise nature strategies, which combine nature-based improved product design with nurture-based maintenance activities (Ertz et al., forthcoming). Although it is not befitting to draw general conclusions from such a small and non-representative sample, when taking a more comprehensive overview of third-party healthcare product providers, it appears that nature is also comparatively less prevalent than other PLE activities hence a nature-based perspective is less prominent than nurture orientation. In fact, other OEM such as Siemens Healthineers, GE Healthcare, or Philips Healthcare in general focus on maintenance and recovery, especially repair, to ensure product quality instead of having recourse to improved design right from the start. Yet, in contrast to competitors, Philips developed an area of specialization through the acquisition of AGITO, because this enabled the firm to complement core maintenance and recovery activities with access solutions, thus not only expanding its 
PLE activities but also its revenue sources. The integration of additional PLE activities may therefore constitute a sustainable and strategic move for firms.

\subsection{Barrier to the implementation of product lifetime extension business models}

In this study, we selected firms that focused on PLE to some extent in their business model and were successful in pursuing such orientations. Yet, not all third-party contractors in the healthcare sector pursue such objectives, and it is unclear whether they can and should all engage in PLE. The following identifies some key barriers that prevent organizations from implementing PLE:

- Competition is particularly acute and based on quality and user safety rather than on sustainability. Clients will always weigh quality, flexibility, and price higher than sustainability matters so that PLE-oriented business models need to provide similar if not superior levels of quality and flexibility at lower costs.

- PLE activities require a reconfiguration in the business model with heavy investments in nature and/or nurture strategies. Nature strategies will require the implementation of tools, techniques, processes, and human resources to deploy a robust design process from ideation to implementation. Nurture strategies require similar investments in equipment, workers, systems and procedures to ensure for example reverse logistics for recovery, repair services for recovery, access schemes, redistribution platforms, or maintenance contracts.

- Industry concentration such as the acquisition of AGITO Medical by the publicly listed company Philips, is an opportunity but also a double-edged sword. Small PLE-oriented start-ups and organizations have the liberty to be creative and devise PLE initiatives without the constraint of maximizing shareholder value. When acquired by a public limited company with public shares and imperatives to maximize short-term shareholder value, creativity in PLE initiatives may be hindered by the tendency to reenact financially lucrative PLE activities to ensure a continuous 
stream of profits. Although the larger corporation provides scale and advantage to the smaller firm, this comes at the price of constrained innovativeness and sub-optimal PLE.

These barriers apply typically to large-scale organizations. Yet, end consumers, such as those served by Layer, for example, are influenced by a variety of factors affecting their attitudes and behavior toward products in general, and pre-owned or shared resources in particular. Consumers seek prestige, distinction (Bourdieu, 1979), and status through consumption (Veblen, 1899/1979). Other socio-cultural and psychological factors affecting consumption have been well emphasized in cultural studies, consumer behavior literature and marketing (Cooper, 2004, 2010). Overall, consumers seek convenience, novelty and choice. Pre-owned products may appear not socially gratifying or novel enough (Roux and Korchia, 2006), accessed products may be considered as too scarce (Lamberton and Rose, 2012) and give way to negative reciprocity (Bardhi and Eckhardt, 2012), while longer-lasting products with premium prices may be considered as being too expensive. Education to make consumers more fully cognizant of the impacts of their purchases is a good mean to raise awareness and provoke change in consumer behavior (Bocken and Short, 2016). The implementation of such education programs goes however beyond firms in the healthcare sector and involves policy-makers as well as community leaders. Healthcare institutions are traditionally engaged in consumer health education and might thus act as significant contributors to inform consumers about the importance of extending healthcare product lifetimes.

\subsection{Theoretical implications}

The notion of product lifetime extension combining nature (i.e., improved design) strategies with nurture strategies involving access, redistribution, maintenance and recovery, has long been considered as a means to curb product disposition and solid waste (Cox et al., 2013; Bakker et al., 2014a, 2014b). While the concept has gained traction in a number of different sectors and areas, the healthcare sector has been slower to take this shift. Yet, the literature is ripe with studies on the detrimental environmental impacts of health care systems and their effect on public health (Eckelman and Sherman, 2016; Eckelman et al., 
2018; Malik et al., 2018). Consequently, a literature stream has started to investigate how healthcare products could be managed more appropriately to reduce their adverse environmental and social impacts (e.g., Kane et al., 2018). This study contributes to this emerging field of research.

This paper advocates framing product lifetime extension as a driver for business model innovation as well as for sustainability in the healthcare sector. PLE should be considered as a central strategic perspective to business for healthcare third-party providers rather than a peripheral consideration that is framed in discontinuous corporate social responsibility programs or public relation activities. The PLEBM framework (Ertz et al., forthcoming) constituted a useful map to analyze and benchmark different study cases. PLE is a source of creativity and innovation for organization while also a strategic tool for differentiation, positioning and business profitability.

Each case study organization framed PLE into a compelling business proposition although for some PLE was non-core to the value proposition. Yet, what all these examples tell about the possibility of reforming the healthcare sector in general and third-party contractors in particular, is that the road for sustainability need not be distant from business considerations and in fact aligns fruitfully with business considerations and imperatives. The key is to ensure that the business model is build coherently enough so that all the dimensions harmoniously coordinate with each other to offer value to clients. In section 5.1. of the discussion we elaborated on the characteristics of two broad strategic orientations for PLE in the healthcare sector. Other more nuanced and specialized configurations might be drawn from the cases or from the application of the PLEBM to other cases. While this study focused on third-party contractors because they play an essential role in supplying and serving the various product needs of healthcare institutions, future research could also analyze PLE at the level of healthcare providers such as hospitals, clinics, laboratories or bioengineering departments in order to get a more complete understanding of the healthcare value chain.

\section{Conclusions}


This study provides an overview of the deployment of product lifetime extension in business models of third-party contractors in the healthcare sector. The paper provided useful insights into the various means and ways an organization might contribute to decrease product waste in the hea;thcare sector by extending medical product lifetimes.

Through a variety of study cases, this study showed to what extent product lifetime extension can be a central to the business model of a healthcare equipment provider, instead of just being an ad hoc initiative or an add-on to the current business operations. More specifically, PLE initiatives range from secondary to core, with core PLE meaning that PLE is embedded in the business model fabric. Whether core or secondary to the business value proposition, a PLE approach can provide additional business opportunities, markets, and revenue sources to a given organization.

Most importantly, other sustainability orientation such as sufficiency-based business models, a demand reduction and voidance-inducing strategy (Dyllick and Hockerts, 2002; Young and Tilley, 2006; Bocken et al., 2015), that are typically more suitable for new start-ups and smaller organizations, have been more questionable for multi-nationals or publicly-listed firms that would suffer from demand reduction Bocken and Short, 2016). In contrast, in line with previous findings (e.g., Ertz et al., forthcoming; Gaiardelli et al., 2014), this study shows that PLE-based business models fit in small-, medium-, and large-sized organizations. However, not all PLE strategies are equally popular especially among large corporations and it appears that improved design activities seem as difficult to implement in larger organizations than sufficiency-based strategies. Future research should explore more specifically how nature strategies such as improved design might be implemented in third-party contractors in general, and larger organizations, in particular.

Somewhat related to the previous point, although the models presented in the study case are successful, many barriers remain to the implementation and continuation of PLE activities in the specific context of healthcare. While two out of the three study cases are publicly-listed firms, AGITO Medical 
has been integrated into the broader Philips groups only recently. It would be of interest to determine whether going public has an impact on the organization's creative impetus and innovation with regards to PLE. In sum, what are the best contributors to PLE : start-ups, free-lance professionals and small organizations or medium-sized and larger one? Do firm size and type matter at all for PLE innovation embedded in business models? Future research could investigate this issue in more details.

The research was limited to the consideration of third-party contractors from developed countries. While a huge number of such organizations do indeed evolve in developed economies, there are many avenues for future research in exploring the extent to PLE initiatives in the healthcare sector are applicable in other parts of the world, especially those with growing populations such as India, Africa and South-East Asia, in which pressures on the environment and resources intensify. Other political and cultural contexts with diverse healthcare service settings are also worth exploring in more details.

\section{Acknowledgements}

This work was supported by grant the Fonds de Recherche du Québec - Société et Culture's (FRQSC) Research Support for New Academics grant [2020-NP-267004]. We would also like to thank the case companies for their time and rich insights.

\section{References}

Abouelmehdia, K. Beni-Hssanea A. Khaloufia H. \& Saadib M. (2017). Big healthcare data: preserving security and privacy. Journal of Big Data, 5(1).

Bakker, C., den Hollander, M.C., Van Hinte, E., \& Zijlstra, Y. (2014b, eds.). Products that last: Product Design for Circular Business Models. Delft, The Netherlands: Delft Library/Marcel den Hollander IDRC.

Bakker, C., Wang, F., Huisman, J., \& den Hollander, M. (2014a). Products that go round: Exploring product life extension through design. Journal of Cleaner Production, 69, 10-16.

Bardhi, F. \& Eckhardt, G. M. (2012). Access-based consumption: The case of car sharing. Journal of consumer research, 39(4), 881-898.

Bhamra, T., \& Hon, B. (2004). Design and Manufacture for Sustainable Development 2004. Bury St Edmunds: Professional Engineering Publishing Limited.

Bocken, N. \& Short, S. (2016). Towards a sufficiency-driven business model: Experiences and opportunities. Elsevier Environmental Innovation and Societal Transitions, 18, 41-61.

Bocken, N. M. P., Rana, P., \& Short, S. W. (2015). Value mapping for sustainable business thinking. Journal of Industrial and Production Engineering, 32(1), 67-81. 
Bocken, N. M., \& Short, S. W. (2016). Towards a sufficiency-driven business model: Experiences and opportunities. Environmental Innovation and Societal Transitions, 18, 41-61.

Bourdieu, P. (1979). La distinction. Paris: Le sens commun.

Box, J. M. (1983). Extending product lifetime: Prospects and opportunities. European Journal of Marketing, 17(4), 34-49.

Campion, N., Thiel, C. L., Woods, N. C., Swanzy, L., Landis, A. E., \& Bilec, M. M. (2015). Sustainable healthcare and environmental life-cycle impacts of disposable supplies: a focus on disposable custom packs. Journal of Cleaner Production, 94, 46-55.

Cooper, J. S., \& Fava, J. A. (2006). Life-Cycle assessment practitioner survey: Summary of results. Journal of Industrial Ecology, 10(4), 12-14.

Cooper, T. (1994). Beyond recycling: The longer life option. Available at: http://irep.ntu.ac.uk/id/eprint/24666/1/201125_7266\%20Cooper\%20Publisher.pdf (accessed on $01 / 06 / 2019$ ).

Cooper, T. (2004). Inadequate life? Evidence of consumer attitudes to product obsolescence. Journal of Consumer Policy, 27(4), 421-449.

Cooper, T. (2010). Longer lasting products: alternatives to the throwaway society. New York, NY: Routledge.

Cormican, K. \& O'connor, M. (2009). Technology Transfer For Product Life Cycle Extension: A Model For Successful Implementation. https://doi.org/10.1142/S0219877009001698

Cox, J., Griffith, S., Giorgi, S., \& King, G. (2013). Consumer understanding of product lifetimes. Resources, Conservation and Recycling, 79, 21-29.

Den Hollander, M.C., Bakker, C.A., \& Hultink, E.J. (2017). Product design in a circular economy: Development of a typology of key concepts and terms. Journal of Industrial Ecology, 21(3), 517-525.

Despeisse, M., Baumers, M., Brown, P., Charnley, F., Ford, S. J., Garmulewicz, A., ... \& Rowley, J. (2017). Unlocking value for a circular economy through 3D printing: A research agenda. Technological Forecasting and Social Change, 115, 75-84.

DMD Connects (2015). Extending the Pharma Product Life Cycle. Available at: https://www.dmdconnects.com/blog/extending-the-pharma-product-life-cycle (accessed on 01/06/2019).

Dyllick, T. \& Hockerts, K. (2002). Beyond the business case for corporate sustainability. Business strategy and the environment, 11(2), 130-141.

Eckelman, M., Mosher, M, Gonzalez, A., \& Sherman, J., (2012). Comparative Life Cycle Assessment of Disposable and Reusable Laryngeal Mask Airways. Anesthesia \& Analgesia. 114(5), 10671072.

Eckelman, M.J. \& Sherman, J.D. (2016). Environmental Impacts of the U.S. Health Care System and Effects on Public Health. PLoS ONE, 11(6), e0157014.

Eckelman, M.J., Sherman, J.D. \& MacNeill, A.J. (2018). Life cycle environmental emissions and health damages from the Canadian healthcare system: An economic-environmental-epidemiological analysis. PLOS Medicine, 15(7), e1002623.

Ertz, M. Leblanc-Proulx, S., Sarigollu, E., \& Morin, V (2019a). Advancing quantitative rigor in the circular economy literature: New methodology for product lifetime extension business models. Resources, Conservation \& Recycling, 150, 104437.

Ertz, M. Leblanc-Proulx, S., Sarigollu, E., \& Morin, V (2019b). A taxonomy of business models on product lifetime extension. Journal of Cleaner Production, 234, 867-880.

Finnveden, G., Hauschild, M. Z., Ekvall, T., Guinée, J., Heijungs, R., Hellweg, S., ... \& Suh, S. (2009). Recent developments in life cycle assessment. Journal of environmental management, 91(1), $1-21$.

Gaiardelli, P., Resta, B., Martinez, V., Pinto, R. \& Albores, P. (2014). A classification model for productservice offerings. Journal of Cleaner Production, 66, 507-519. 
Hanson, J. W. (1980). A proposed paradigm for consumer product disposition processes. Journal of consumer affairs, 14(1), 49-67.

Harrell, G. D. \& McConocha, D. M. (1992). Personal factors related to consumer product disposal tendencies. Journal of Consumer Affairs, 26(2), 397-417.

Hartmann, P. M., Zaki, M., Feldmann, N., \& Neely, A. (2016). Capturing value from big data-a taxonomy of data-driven business models used by start-up firms. International Journal of Operations \& Production Management, 36(10), 1382-1406.

Heiskanen, E. (1996). Conditions for product life extension. National Consumer Research Centre Working Papers, 22.

Kagawa, S., Tasaki, T., \& Moriguchi, Y. (2006). The environmental and economic consequences of product lifetime extension: Empirical analysis for automobile use. Ecological Economics, 58(1), 108-118.

Kaiser, B., Eagan, P. \& Shaner H.,(2001). Solutions to Health Care Waste: Life-Cycle Thinking and "Green" Purchasing. Available at: https://ehp.niehs.nih.gov/doi/pdf/10.1289/ehp.01109205 (accessed on 31/05/2019).

Kane, G.M., Bakker, C.A. \& Balkenende, A.R. (2018). Toward design strategies for circular medical products. Resources, Conservation and Recycling, 135, 38-47.

Karlsson, M. \& Öhman, D. (2005). Material consumption in the healthcare sector: Strategies to reduce its impact on climate change - The case of Region Scania in South Sweden. Journal of Cleaner Production Volume (13), 1071-1081

Kostecki, M. (Ed.) (1998). The durable use of consumer products. Dordrecht, The Netherlands: Kluwer

Lamberton, C. P. \& Rose, R. L. (2012). When is ours better than mine? A framework for understanding and altering participation in commercial sharing systems. Journal of Marketing, 76(4), 109125.

Lewandowski, M. (2016). Designing the business models for circular economy-Towards the conceptual framework. Sustainability, 8(1), 43-71.

Maldini, I., Stappers, P. J., Gimeno-Martinez, J. C., \& Daanen, H. A. (2019). Assessing the impact of design strategies on clothing lifetimes, usage and volumes: The case of product personalisation. Journal of Cleaner Production, 210, 1414-1424.

Malik, A., Lenzen, M., McAlister, S.M. \& McGain, F. (2018). The carbon footprint of Australian health care. The Lancet Planetary Health, 2(1), PE27-E35.

Martin, D. M., \& Schouten, J. (2012). Sustainable marketing. New York, NY: Pearson Prentice Hall.

McCoy, M. (1997). Angling for Endurance. In E. Van Hinte (Ed.), Eternally Yours: Visions on Product Endurance (pp. 190-201). Amsterdam: 010 Publishers.

Mont, O.K. (2002). Clarifying the concept of product-service system. Journal of Cleaner Production, 10, 237-245.

Nishijima, D. (2017). The role of technology, product lifetime, and energy efficiency in climate mitigation: A case study of air conditioners in Japan. Energy Policy, 104, 340-347.

Nosratabadi, S., Mosavi, A., Shamshirband, S., Kazimieras Zavadskas, E., Rakotonirainy, A., \& Chau, K. W. (2019). Sustainable Business Models: A Review. Sustainability, 11(6), 1663-1693.

Nussholz, J.L.K. (2017). Circular business models: Defining a concept and framing an emerging research field. Sustainability, 9(1810), 1-16.

Okoye, H. (2015). Product Life Cycle and How it Relates to Healthcare. Available at: https://www.ausmed.com/cpd/articles/product-life-cycle-relates-healthcare (accessed on 01/06/2019).

Osterwalder, A. \& Pigneur, Y. (2010). Business model generation: a handbook for visionaries, game changers, and challengers. John Wiley \& Sons.

Patton, M.Q. (2002). Qualitative, research \& evaluation methods. Thousand Oaks, CA: Sage publications Inc.

Prahalad, C. K., \& Ramaswamy, V. (2004). Co-creation experiences: The next practice in value creation. Journal of interactive marketing, 18(3), 5-14. 
Roux, D. \& Korchia, M. (2006), Am I What I Wear? An Exploratory Study of Symbolic Meanings Associated with Secondhand Clothing, Advances in Consumer Research, 33, 1, 29-35.

Saghbini, J. (2016). Supply Chain as a Strategic Asset: Eliminating Waste in the Medical Device Supply Chain inventory management. Available at: https://www.dicardiology.com/article/supplychain-strategic-asset-eliminating-waste-medical-device-supply-chain (accessed on 01/06/2019).

Sherman, J., Le, C., Lamers, V., \& Eckelman, M. (2012). Life Cycle Greenhouse Gas Emissions of Anesthetic Drugs. Anesthesia \& Analgesia, 114(5), 1086-1090.

Simon, M., Allman, L., Yang, K., \& Cock, T. (2004). Product design informed by life-cycle information - initial results from ELIMA. In T. Bhamra and B. Hon (Eds.), Design and manufacture for sustainable development (pp. 103-112). Bury St Edmunds: Professional Engineering Publishing Limited.

Smith, B. D., Tarricone, R., \& Vella, V. (2013). The role of product life cycle in medical technology innovation. Journal of Medical Marketing, 13(1), 37-43.

The Ellen MacArthur Foundation (2015). Growth within: a circular economy vision for a competitive Europe. Available at: https://www.ellenmacarthurfoundation.org/assets/downloads/publications/EllenMacArthurFo undation_Growth-Within_July15.pdf (accessed 12-10-2018).

Tran L. (2016). Project Management Lessons for the Healthcare Industry. Available at: https://www.inloox.com/company/blog/articles/5-project-management-lessons-for-thehealthcare-industry/ (accessed on 01/06/2019).

Tukker, A. (2004). Eight types of product-service system: Eight ways to sustainability? Experiences from SusProNet. Business Strategy \& the Environment, 13, 246-260.

Tunn, V. S. C., Bocken, N. M. P., van den Hende, E. A., \& Schoormans, J. P. L. (2019). Business models for sustainable consumption in the circular economy: An expert study. Journal of Cleaner Production, 212, 324-333.

United Nations (2017). World population ageing. Available at: https://www.un.org/en/development/desa/population/publications/pdf/ageing/WPA2017_Hig hlights.pdf (accessed on 30/05/2019).

Van Hinte, E. (Ed.) (1997). Eternally yours: Visions on product endurance. Rotterdam, The Netherlands: OIO Publishers.

Van Nes, N., \& Cramer, J. (2003). Design strategies for the lifetime optimisation of products. The Journal of Sustainable Product Design, 3(3-4), 101-107.

Van Nes, N., \& Cramer, J. (2005). Influencing product lifetime through product design. Business Strategy and the Environment, 14(5), 286-299.

Van Nes, N., \& Cramer, J. (2006). Product lifetime optimization: a challenging strategy towards more sustainable consumption patterns. Journal of Cleaner Production, 14(15-16), 1307-1318.

Veblen, T. (1899/1979). Theory of the leisure class. Paris : Gallimard.

Wilhelm, W. B. (2012). Encouraging sustainable consumption through product lifetime extension: The case of mobile phones. International Journal of Business and Social Science, 3(3), 17-32.

Yin, R. (2014). Case Study Research: Design and Methods $\left(5^{\text {th }}\right.$ ed.). Thousand Oaks, CA: SAGE Publications, Inc.

Young, W. \& Tilley, F. (2006). Can businesses move beyond efficiency? The shift toward effectiveness and equity in the corporate sustainability debate. Business Strategy and the Environment, 15(6), 402-415.

Zhong, S. \& Pearce, J. M. (2018). Tightening the loop on the circular economy: Coupled distributed recycling and manufacturing with recyclebot and RepRap 3-D printing. Resources, Conservation and Recycling, 128, 48-58. 


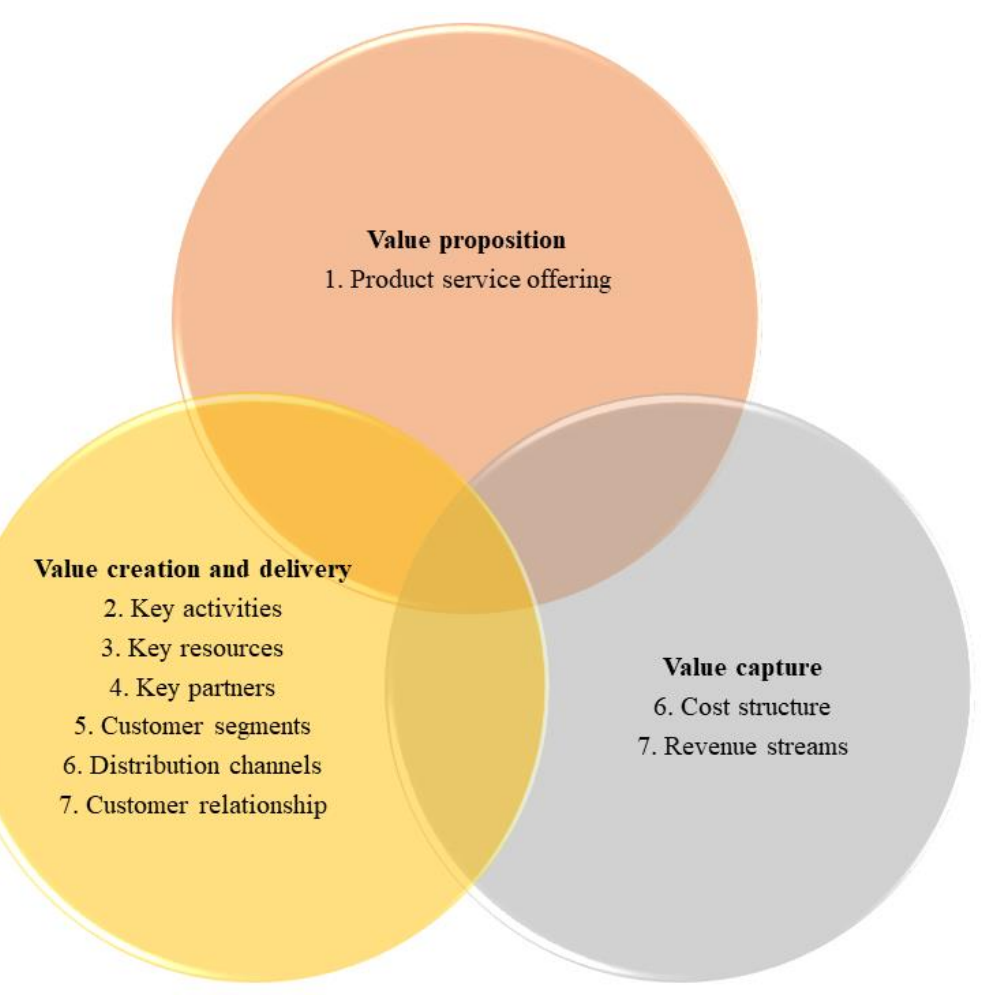

Source: adapted from Osterwalder and Pigneur (2010) and Hartmann et al. (2016)

Figure 1. The business model canvass 


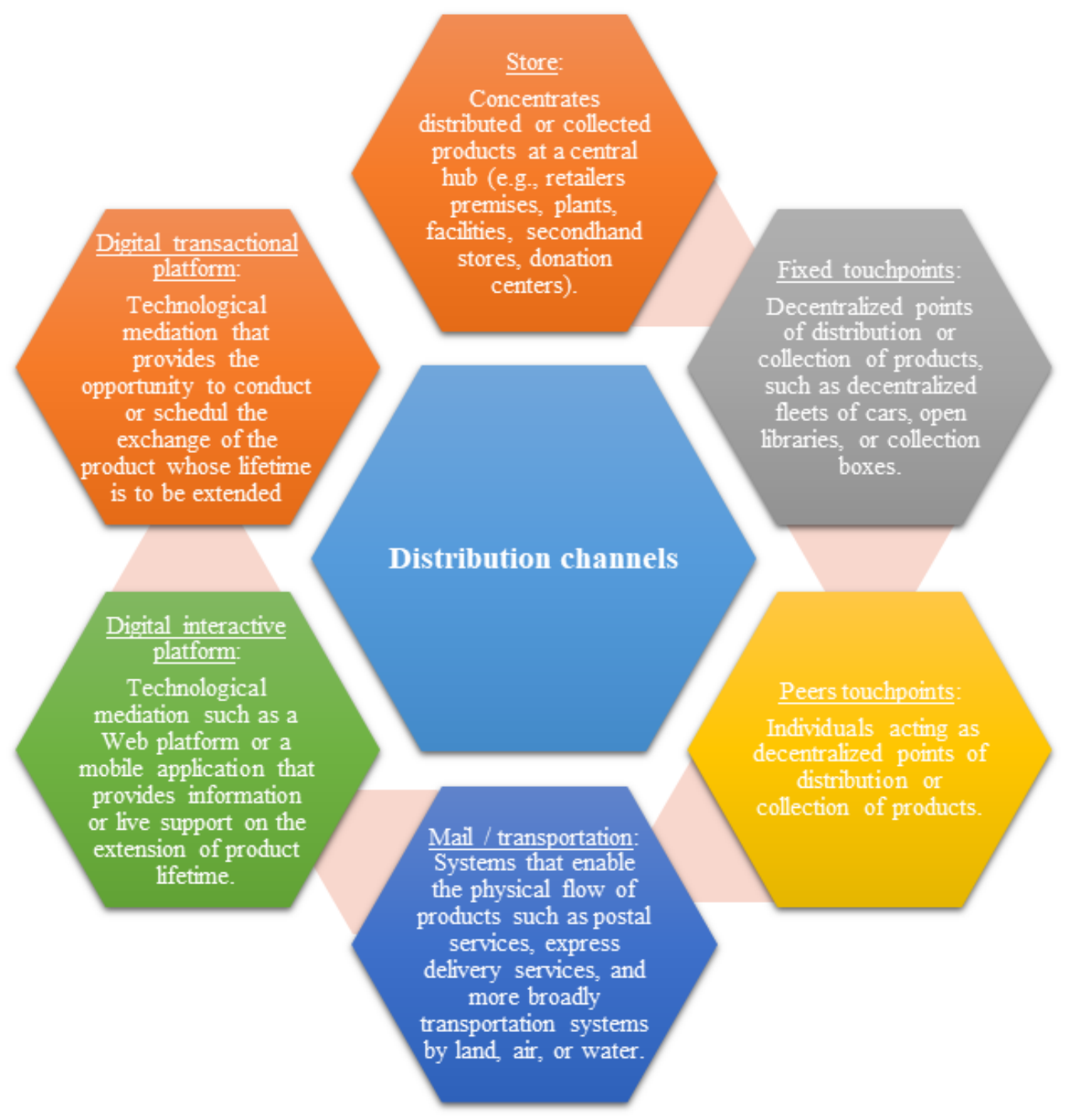

Source: adapted from Ertz et al. (forthcoming).

Figure 2. The channel of product lifetime extension 


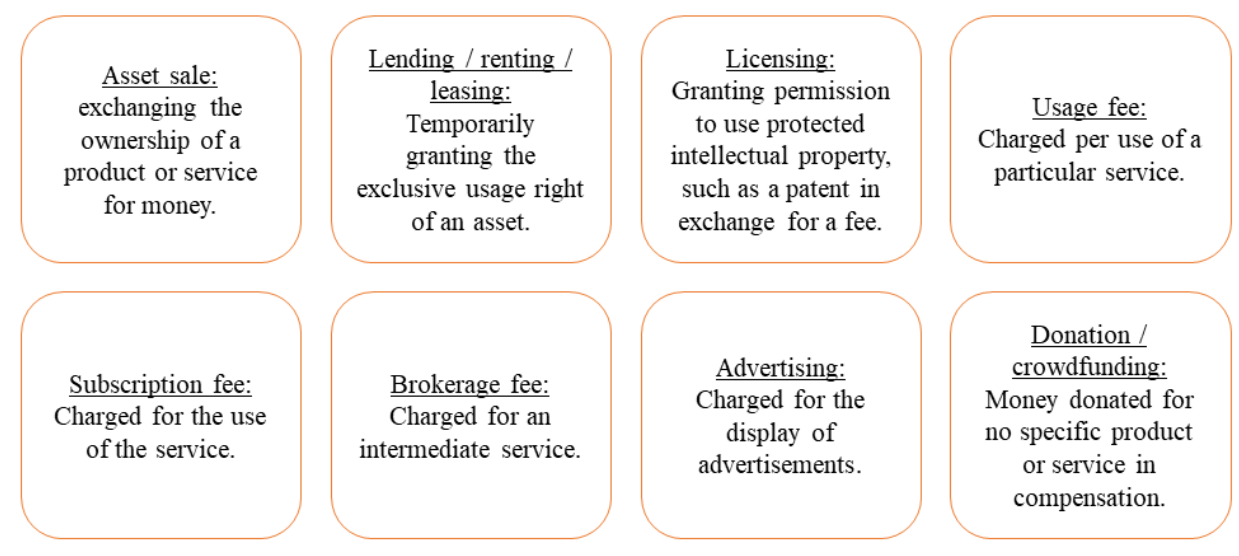

Source: adapted from Ertz et al. (forthcoming).

Figure 3. Revenue streams accruing from product lifetime extension activities 
Table 1. Organizational details

\begin{tabular}{|c|c|c|c|c|c|c|c|}
\hline $\begin{array}{l}\text { Case } \\
\text { company }\end{array}$ & Main Product & $\begin{array}{l}\text { Product } \\
\text { lifetime } \\
\text { extension } \\
\text { activities }\end{array}$ & size & Presence & Source of info & Activities & Industry \\
\hline Stericycle & $\begin{array}{l}\text { Medical waste } \\
\text { management }\end{array}$ & $\begin{array}{l}\text { Product } \\
\text { recalls, } \\
\text { returns, and } \\
\text { retrieval; } \\
\text { environment } \\
\text { al } \\
\text { consulting } \\
\text { services }\end{array}$ & Large & Worldwide & $\begin{array}{l}\text { Field visit } \\
\text { Web/brochure } \\
\text { content } \\
\text { analysis } \\
\text { Interview } \\
\text { (regional } \\
\text { manager) }\end{array}$ & $\begin{array}{l}\text { Services and } \\
\text { wastes } \\
\text { management }\end{array}$ & $\begin{array}{l}\text { Health and } \\
\text { Environmenta } \\
1\end{array}$ \\
\hline Layer & $\begin{array}{l}\text { Medical } \\
\text { manufacturer }\end{array}$ & $\begin{array}{l}\text { Superior } \\
\text { medical } \\
\text { product } \\
\text { design } \\
\text { through } \\
\text { industrial } \\
\text { design and } \\
\text { digital } \\
\text { design } \\
\end{array}$ & Small & Europe & $\begin{array}{l}\text { Web content } \\
\text { analysis }\end{array}$ & $\begin{array}{l}\text { Services and } \\
\text { industrial } \\
\text { technology } \\
\text { manufacturer }\end{array}$ & $\begin{array}{l}\text { Industry and } \\
\text { Technological }\end{array}$ \\
\hline $\begin{array}{l}\text { Agito } \\
\text { Medical }\end{array}$ & $\begin{array}{l}\text { Pre-owned } \\
\text { medical } \\
\text { equipment }\end{array}$ & 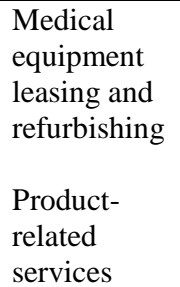 & Medium & $\begin{array}{l}\text { Denmark, } \\
\text { France, The } \\
\text { Netherlands }\end{array}$ & $\begin{array}{l}\text { Web content } \\
\text { analysis } \\
\text { Interview (key } \\
\text { account } \\
\text { manager) }\end{array}$ & $\begin{array}{l}\text { Imaging } \\
\text { equipment } \\
\text { solutions } \\
\text { provider }\end{array}$ & $\begin{array}{l}\text { Healthcare } \\
\text { sector }\end{array}$ \\
\hline
\end{tabular}

Note: 0-100 is considered a small-sized business; 100-999 is considered a medium-sized business; 1000 and over is considered a large company. 
Table 2. Summary of the cases as product lifetime extension business models

\begin{tabular}{|l|l|l|}
\hline \multicolumn{1}{|c|}{ Stericycle } & \multicolumn{1}{|c|}{ Layer } & \multicolumn{1}{c|}{ AGITO Medical } \\
\hline $\begin{array}{l}\text { Adopts PLE as core to the business } \\
\text { offering by re-purposing healthcare } \\
\text { waste in the interest of both the }\end{array}$ & $\begin{array}{l}\text { Adopts PLE as secondary to the } \\
\text { business offering by focusing } \\
\text { primarily on industrial and digital } \\
\text { society and the environment; adopts } \\
\text { and promotes a stewardship role and } \\
\begin{array}{l}\text { adjusts constantly to sustainability } \\
\text { demand. }\end{array}\end{array}$ & $\begin{array}{l}\text { Adopt PLE as core to the business } \\
\text { offering by redistributing, providing } \\
\text { access and maintenance to pre- } \\
\text { techowed medical equipment as an } \\
\text { incidentally longer lifetimes. }\end{array}$ \\
\hline
\end{tabular}


Table 3. Application of the product lifetime extension business model to the three cases

\begin{tabular}{|c|c|c|c|}
\hline & Stericycle & Layer & AGITO Medical \\
\hline \multicolumn{4}{|c|}{ Value proposition } \\
\hline Offering & $\begin{array}{l}\text { Core: essence of the } \\
\text { business model }\end{array}$ & $\begin{array}{l}\text { Secondary: not the } \\
\text { essence of the business } \\
\text { model }\end{array}$ & $\begin{array}{l}\text { Core: essence of the } \\
\text { business model }\end{array}$ \\
\hline \multicolumn{4}{|c|}{ Value creation and delivery } \\
\hline Key resources & Pre-owned products & $\begin{array}{l}\text { New or pre-owned parts, } \\
\text { components and raw } \\
\text { materials }\end{array}$ & $\begin{array}{l}\text { New or pre-owned } \\
\text { products }\end{array}$ \\
\hline Key activities & $\begin{array}{l}\text { Access: short-term and } \\
\text { long-term provision of } \\
\text { materials to medical } \\
\text { establishment } \\
\text { Maintenance: product- } \\
\text { oriented service, } \\
\text { consisting of } \\
\text { replacements and advice } \\
\text { contracts } \\
\text { Redistribution : sale of } \\
\text { new and pre-owned } \\
\text { medical supply materials } \\
\text { and complaint based } \\
\text { solutions } \\
\text { Recovery: product } \\
\text { remanufacturing and } \\
\text { replacement }\end{array}$ & $\begin{array}{l}\text { Design: applying } \\
\text { industrial design and } \\
\text { digital design to craft } \\
\text { longer-lasting products } \\
\text { Maintenance: product- } \\
\text { oriented service, } \\
\text { consisting of } \\
\text { replacements and advice } \\
\text { contracts }\end{array}$ & $\begin{array}{l}\text { Access: short-term and } \\
\text { long-term rental } \\
\text { solutions including } \\
\text { sporadic and made-to- } \\
\text { order fixed site rental } \\
\text { solution } \\
\text { Maintenance: product- } \\
\text { oriented services } \\
\text { consisting of } \\
\text { maintenance and advice } \\
\text { contracts } \\
\text { Redistribution : sale of } \\
\text { tested, pre-owned } \\
\text { medical equipment } \\
\text { Recovery: product repair } \\
\text { as well as } \\
\text { remanufacturing, } \\
\text { refurbishing, and } \\
\text { reconditioning through } \\
\text { trade-in }\end{array}$ \\
\hline Key partners & $\begin{array}{l}\text { Organizations: hospitals, } \\
\text { clinics, laboratories, } \\
\text { automobile industry, } \\
\text { aviation industry and } \\
\text { distributors world-wide }\end{array}$ & $\begin{array}{l}\text { Organizations: for the } \\
\text { ideation process }\end{array}$ & $\begin{array}{l}\text { Organizations: hospitals, } \\
\text { clinics, laboratories, and } \\
\text { distributors world-wide }\end{array}$ \\
\hline Channels & $\begin{array}{l}\text { Store: World-wide } \\
\text { Mail/transportation: } \\
\text { transportation of sold to } \\
\text { landfills, factories and } \\
\text { recycling facilities } \\
\text { Direct: technicians and } \\
\text { agents providing } \\
\text { maintenance and advice } \\
\text { services as well as } \\
\text { laboratory packing, } \\
\text { removal, and } \\
\text { transportation }\end{array}$ & $\begin{array}{l}\text { Store: England } \\
\text { Mail/transportation: } \\
\text { transportation of sold, } \\
\text { Direct: technicians and } \\
\text { agents providing } \\
\text { maintenance and advice } \\
\text { services as well as } \\
\text { dismantling, packing, } \\
\text { removal, and } \\
\text { transportation }\end{array}$ & $\begin{array}{l}\text { Store: offices in } \\
\text { Denmark, France, and } \\
\text { The Netherlands } \\
\text { Mail/transportation: } \\
\text { transportation of sold, } \\
\text { traded-in or rented } \\
\text { products } \\
\text { Direct: technicians and } \\
\text { agents providing } \\
\text { maintenance and advice } \\
\text { services as well as } \\
\text { dismantling, packing, }\end{array}$ \\
\hline
\end{tabular}




\begin{tabular}{|c|c|c|c|}
\hline & $\begin{array}{l}\text { Digital interactive } \\
\text { platform: informative } \\
\text { website }\end{array}$ & $\begin{array}{l}\text { Digital interactive } \\
\text { platform: informative } \\
\text { website and application }\end{array}$ & $\begin{array}{l}\text { removal, and } \\
\text { transportation } \\
\text { Digital interactive } \\
\text { platform: informative } \\
\text { website }\end{array}$ \\
\hline Customer segments & $\begin{array}{l}\text { B2B : clinics, hospitals, } \\
\text { laboratories, local } \\
\text { residence and other } \\
\text { industries and worldwide } \\
\text { distributions }\end{array}$ & $\begin{array}{l}\text { B2B, B2C: serves all } \\
\text { sorts of industries } \\
\text { worldwide }\end{array}$ & $\begin{array}{l}\text { B2B: clinics, hospitals, } \\
\text { laboratories, distributors, } \\
\text { and original equipment } \\
\text { manufacturers worldwide }\end{array}$ \\
\hline Customer relationships & $\begin{array}{l}\text { Transactional and } \\
\text { interactive: two-time } \\
\text { product } \\
\text { exchange } \\
\text { Relational: longer-term } \\
\text { maintenance or supply } \\
\text { contract }\end{array}$ & $\begin{array}{l}\text { Transactional and } \\
\text { interactive: two-time } \\
\text { product } \\
\text { exchange } \\
\text { Relational: longer-term } \\
\text { maintenance or design } \\
\text { contracts }\end{array}$ & $\begin{array}{l}\text { Transactional: one-time } \\
\text { product exchange } \\
\text { Relational: longer-term } \\
\text { maintenance, supply or } \\
\text { renting contracts }\end{array}$ \\
\hline \multicolumn{4}{|l|}{ Value capture } \\
\hline Revenue stream & $\begin{array}{l}\text { Asset sale: selling of } \\
\text { returned, recalled or } \\
\text { retrieved products and } \\
\text { complementary services } \\
\text { (e.g., warranty) } \\
\text { Usage fee: product } \\
\text { return, recall or retrieval } \\
\text { service, and education / } \\
\text { training / consultancy } \\
\text { programs }\end{array}$ & $\begin{array}{l}\text { Asset sale: selling of } \\
\text { prototype products and } \\
\text { complementary services } \\
\text { (e.g., warranty) }\end{array}$ & $\begin{array}{l}\text { Asset sale: selling of } \\
\text { medical pre-owned } \\
\text { products and } \\
\text { complementary services } \\
\text { (e.g., warranty) } \\
\text { Lending / usage / } \\
\text { subscription fee: medical } \\
\text { equipment rental } \\
\text { solutions and education / } \\
\text { training programs }\end{array}$ \\
\hline
\end{tabular}

